\title{
The effect of uncooked and roll-dried maize starch, alone and mixed in equal quantity with sucrose, on dental caries in the albino rat
}

\author{
By R. M. GREEN AND R. L. HARTLES \\ Department of Dental Sciences, School of Dental Surgery, \\ University of Liverpool
}

(Received 23 August 1966-Accepted 8 September 1966)

\begin{abstract}
r. One hundred and ten weanling rats were distributed between five dietary groups in randomized blocks. Each block was constructed from within a litter and each member of the block received a different diet.

2. The main features of the diets were: group I (twenty-six rats) $72 \%$ sucrose, group 2 (sixteen rats) $72 \%$ uncooked maize starch, group 3 (sixteen rats) $72 \%$ roll-dried maize starch, group 4 (twenty-six rats) $36 \%$ sucrose and $36 \%$ uncooked starch, group 5 (twenty-six rats) $36 \%$ sucrose and $36 \%$ roll-dried starch.

3. The animals were killed after 20 days on the diets and assessed for dental caries. The rats of group I (sucrose) had significantly more caries than all other groups, the rats of group 2 (uncooked starch) had significantly less caries than any of the other groups. Rolldried starch (group 3) produced significantly more caries than uncooked starch (group 2 ). The mixture of uncooked starch and sucrose (group 4) was significantly more cariogenic than the mixture of roll-dried starch and sucrose (group 5).
\end{abstract}

There are wide variations in the incidence of dental caries when rats are maintained on diets containing different carbohydrates. Thus, diets consisting of about two-thirds of sucrose are highly cariogenic, whereas diets containing equivalent amounts of raw potato starch (Hartles \& Lawton, 1957), uncooked wheat starch (Grenby, 1963) or uncooked maize starch (Green \& Hartles, I966a) result in a low incidence of caries. Grenby (I966) has shown that the cariogenicity of a diet containing $67 \%$ dry powdered bread is increased when $10 \%$ of the bread is replaced by sucrose.

The objective of the present study was to determine the effect on the dental caries experience of rats of $(a)$ the heat treatment of maize starch as carried out in rolldrying and $(b)$ the mixture of starch, either uncooked or roll-dried, with equal quantities of sucrose.

\section{EXPERIMENTAL}

\section{Animals and management}

A total of IIo weanling albino rats of both sexes from our own caries-susceptible colony were used. There is no significant variation in caries experience between the sexes in short-term studies (Green \& Hartles, I966 6 ). Eighty rats, five from each of sixteen litters, were assigned, one from each litter, to the five dietary groups. In addition, thirty rats, three from each of ten litters, were assigned, one from each litter, to groups $\mathrm{r}, 4$ and 5 . Thus, comparison of the results from groups of sixteen animals can be made in all instances, and between twenty-six animals in groups 1,4 and 5 . The animals were distributed at random to groups and were housed and main- 
tained as described by Green \& Hartles $(1966 a, c)$. The animals were weighed at the beginning, and at the end of the experiment. They were maintained on their respective diets for 2 I days and then killed by diethyl ether inhalation.

\section{Diets}

Diet RC I4 (group I) was a cariogenic diet described by Green \& Hartles (I966c). Its main components $(\mathrm{g} / \mathrm{kg})$ were sucrose (icing sugar; Tate and Lyle Limited) $7^{20}$, casein (Casein Industries Limited) 240, and salt mixture A (Hartles \& Leaver, I961) 40. Water-soluble and fat-soluble vitamins (in a water-miscible form) were added to the diet dispersed in water. The diet contained no added fat; this increased its cariogenicity, and permitted satisfactory growth during the period of the experiment.

Diet RC 17 (group 2) was as RC I4 except that the sucrose was replaced by uncooked maize starch (Corn Products Limited).

Diet RC I8 (group 3) was as RC I4 except that sucrose was replaced by roll-dried maize starch (Corn Products Limited).

Diet RC I9 (group 4) was as RC I4 except that half the sucrose was replaced by uncooked maize starch.

Diet RC 20 (group 5) was as RC I4 except that half the sucrose was replaced by roll-dried maize starch.

The diets and de-ionized water were provided in unrestricted amounts.

\section{Assessment of dental caries}

The method used for assessing dental caries was essentially that of König, Marthaler \& Mühlemann (I958) as described by Green \& Hartles (I966a).

\section{Utilization of the starches and the starch-sucrose mixtures by human salivary flora}

In order to gain information concerning the relative degree to which the starches and starch-sucrose mixtures can act as substrates for oral micro-organisms, they were tested against samples of whole human saliva in the Warburg microrespirometer. Aqueous suspensions $(\mathrm{r} \%, \mathrm{w} / \mathrm{v})$ of each of the starches and of the two starch-sucrose mixtures were prepared, samples $(0.2 \mathrm{ml})$ were added to $0.5 \mathrm{ml}$ portions of saliva and measurements made manometrically of aerobic metabolism $\left(\mathrm{O}_{2}\right.$ consumption $)$ and anaerobic metabolism $\left(\mathrm{CO}_{2}\right.$ production in the presence of a bicarbonate buffer $)$. The methods were as described by Molan \& Hartles (I966).

\section{RESULTS}

Growth of animals. The animals remained healthy throughout the experiment and grew normally. The extent of the weight gain is shown in Table $I$.

Caries incidence. The results are presented in Table $\mathbf{I}$; dental caries is expressed as the number of lesions per rat, cumulative $T$ includes all lesions, cumulative $B$ includes the more severe lesions, and $C$ represents the most severe (see Green $\&$ Hartles I $966 a$, for system of classification). The results are arranged in two columns, one for 
sixteen animals per group relating to all groups, and one for twenty-six animals per group relating to groups $I, 4$ and 5 .

The total number of lesions present was subjected to an analysis of variance in which the total variation of the experiment was divided into that due to treatments, that due to blocks, and the residual or error variation. The total treatment variation was then further divided into a series of orthogonal comparisons so that each comparison could be given a valid level of significance. The test of significance was Snedecor's $\boldsymbol{F}$-test.

Table 2 shows the within-litter comparisons which have been made, together with their levels of significance. The following conclusions can be drawn. (I) When com-

Table I. Caries experience (assessed by the method of Green \& Hartles, I966a) and total weight gain of five groups of rats maintained on different high-carbohydrate diets for 21 days

\begin{tabular}{|c|c|c|c|c|c|c|c|c|}
\hline \multirow[b]{2}{*}{ Group } & \multirow[b]{2}{*}{ Diet } & \multicolumn{2}{|c|}{$\begin{array}{c}\text { Cumulative } \mathbf{T} \\
\text { (all lesions) }\end{array}$} & \multicolumn{2}{|c|}{$\begin{array}{c}\text { Cumulative B } \\
\text { (more severe } \\
\text { lesions) }\end{array}$} & \multicolumn{2}{|c|}{$\begin{array}{c}\mathrm{C} \\
\begin{array}{c}\text { (most severe } \\
\text { lesions) }\end{array}\end{array}$} & \multirow{2}{*}{$\begin{array}{l}\text { Weight } \\
\text { gain } \\
\text { (g) }\end{array}$} \\
\hline & & $\begin{array}{l}\text { Mean } \\
\text { (I6 rats) }\end{array}$ & $\begin{array}{c}\text { Mean } \\
\text { (26 rats) }\end{array}$ & $\begin{array}{l}\text { Mean } \\
\text { (16 rats) }\end{array}$ & $\begin{array}{c}\text { Mean } \\
\text { (26 rats) }\end{array}$ & $\begin{array}{c}\text { Mean } \\
\text { (I6 rats) }\end{array}$ & $\begin{array}{c}\text { Mean } \\
\text { (26 rats) }\end{array}$ & \\
\hline I & RC i4, sucrose & $7 \cdot 8$ & $7 \cdot 5$ & $4 \cdot 0$ & $3 \cdot 0$ & 0.6 & 0.5 & 62 \\
\hline 2 & $\begin{array}{l}\text { RC i7, uncooked maize } \\
\text { starch }\end{array}$ & 0.9 & - & 0.0 & - & 0.0 & - & 68 \\
\hline 3 & $\begin{array}{l}\mathrm{RC} \text { I8, roll-dried maize } \\
\text { starch }\end{array}$ & $3^{\cdot I}$ & - & 0.6 & - & $0 \cdot 0$ & - & 62 \\
\hline 4 & $\begin{array}{l}\mathrm{RC} \text { rg, sucrose and } \\
\text { uncooked starch }\end{array}$ & $7 \cdot 0$ & $7 \cdot 4$ & 2.5 & $2 \cdot 6$ & 0.4 & 0.4 & 66 \\
\hline \multirow[t]{2}{*}{5} & $\begin{array}{l}\mathrm{RC} 2 \mathrm{o} \text {, sucrose and } \\
\text { and roll-dried starch }\end{array}$ & 5.9 & 6.0 & $2 \cdot 4$ & $\mathrm{I} \cdot 8$ & $O \cdot I$ & O'I & 68 \\
\hline & $\begin{array}{l}\text { Pooled standard error } \\
\text { of group means }\end{array}$ & 0.42 & 0.35 & 0.30 & 0.36 & - & 一 & - \\
\hline
\end{tabular}

Table 2. Within-litter comparisons of the total number of carious lesions in groups of rats arising as a result of different dietary carbohydrates, with the significance level for each comparison

(The number of animals compared is shown in parentheses)

\begin{tabular}{|c|c|c|}
\hline \multicolumn{2}{|c|}{ Dietary treatments compared } & \multirow{2}{*}{$\begin{array}{c}\text { Level of } \\
\text { significance } \\
P<0.001\end{array}$} \\
\hline $\begin{array}{l}\text { Sucrose } \\
\text { Group I (I6) }\end{array}$ & $\begin{array}{l}\text { v. all other diets } \\
\text { Groups 2, 3, } 4 \text { and } 5(64)\end{array}$ & \\
\hline $\begin{array}{l}\text { Starches } \\
\text { Groups } 2 \text { and } 3(\mathbf{3 2})\end{array}$ & $\begin{array}{l}\text { v. sucrose/starch mixtures } \\
\text { Groups } 4 \text { and } 5\left(3^{2}\right)\end{array}$ & $P<0.001$ \\
\hline $\begin{array}{l}\text { Uncooked starch } \\
\text { Group } 2 \text { (16) }\end{array}$ & $\begin{array}{l}\text { voli-dried starch } \\
\text { Group } 3 \text { (16) }\end{array}$ & $P<0.00 \mathrm{r}$ \\
\hline $\begin{array}{l}\text { Sucrose and uncooked starch } \\
\text { Group } 4 \text { (I6) }\end{array}$ & $\begin{array}{l}\text { v. sucrose and roll-dried starch } \\
\text { Group } 5 \text { (16) }\end{array}$ & $P<0.05$ \\
\hline $\begin{array}{l}\text { Sucrose } \\
\text { Group I (26) }\end{array}$ & $\begin{array}{l}\text { v. sucrose and uncooked starch } \\
\text { Group } 4(26)\end{array}$ & NS \\
\hline \multirow[t]{2}{*}{$\begin{array}{l}\text { Sucrose and roll-dried starch } \\
\text { Group } 5(26)\end{array}$} & $\begin{array}{l}\text { v. sucrose, and sucrose and uncooked starch } \\
\text { Groups I and } 4(52)\end{array}$ & $P<0.001$ \\
\hline & NS, not significant. & \\
\hline
\end{tabular}


pared with the combined results of all other diets, the sucrose diet produced significantly more caries. (2) Starch-sucrose mixtures were significantly more cariogenic than starches. (3) Roll-dried starch produced significantly more caries than uncooked starch. (4) The caries produced on the sucrose diet was demonstrably no different from that produced by the mixture of sucrose and uncooked starch. (5) The sucrose and roll-dried starch diet was significantly less cariogenic than the sucrose and uncooked starch diet.

Utilization of starches and sucrose-starch mixtures by human salivary flora. The relative rate of aerobic and anaerobic metabolism of three samples of human saliva in the presence of the several dietary carbohydrates is shown in Table 3.

The limited information is illustrative of the fact that all the substrates were metabolized by the whole mixed sample of human saliva. The uncooked maize starch was utilized less than the other substrates in anaerobic conditions, but there was little difference in utilization in aerobic conditions.

\section{Table 3. Metabolism of the starch and sucrose-starch mixtures by human salivary flora}

(Aerobic metabolism measured as $\mathrm{O}_{2}$ consumption in air, anaerobic metabolism as $\mathrm{CO}_{2}$ produced in the presence of bicarbonate buffer. Values are the means of three observations)

Substrate

Uncooked maize starch

Roll-dried maize starch

Uncooked starch and sucrose

Roll-dried starch and sucrose

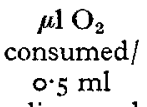

saliva per $h$

${ }_{13}^{8}$

148

127

146 $\mu \mathrm{l} \mathrm{CO}_{2}$

produced/

$0.5 \mathrm{ml}$

saliva per $h$

$25^{8}$

330

322

395

\section{DISCUSSION}

The results of this study were in part predictable, in part not contrary to reasonable expectation, and in part quite unforeseen.

Previous studies have shown that the consumption of a high-sucrose diet causes a moderately severe incidence of dental caries in our rats; conversely a diet in which the sucrose has been completely replaced by uncooked maize starch leads to a low incidence of caries (Green \& Hartles, I $g 66 a, c$ ). These findings have now been confirmed.

It was not unexpected that the roll-drying of the maize starch should significantly increase its cariogenicity. According to the manufacturers, the starch undergoes some hydrolytic degradation as a result of the roll-drying of the starch slurry; the soluble fraction is thereby increased from approximately $0.1 \%$ to about $8.5 \%(\mathrm{w} / \mathrm{v})$. The reducing properties, however, are very feeble, less than $0.1 \%$ when calculated as glucose. It seems probable therefore that the soluble fraction of the roll-dried starch consists of polymers of fairly high molecular weight and very little oligosaccharide. The roll-drying process is unlikely to result in the provision of any simple carbohydrate substrate capable of imrnediate metabolism by the oral flora. It is, however, likely that salivary amylase would hydrolyse the roll-dried starch more readily than the uncooked 
starch thus providing metabolizable substrate at a higher rate. The limited information available (Table 3 ) shows a moderate increase in the anaerobic utilization of starch by human salivary flora as a result of roll-drying but very little effect on aerobic breakdown. This aspect of the problem requires a full investigation before its relevance to cariogenicity can be evaluated.

The replacement of half the dietary sucrose with uncooked starch did not significantly affect the incidence of caries. This finding is in accord with that of Schweigert, Shaw, Phillips \& Elvehjem (1945) who reported, in the cotton-rat, that replacing half the dietary sugar with dextrin does not reduce the severity of dental caries. Rozeik (1958), on the other hand, claimed that a diet containing sucrose plus starch in the form of crushed barley is more cariogenic in the rat than diets containing either constituent alone.

The most intriguing observation, however, was that a diet containing equal quantities $(36 \%)$ of sucrose and roll-dried starch was significantly less cariogenic than a mixture of sucrose and uncooked starch. This finding was unexpected and reinforces the view that it is not necessarily the quantity of carbohydrate in a diet or merely the ease with which it can be converted into acids which governs its cariogenicity; it emphasizes the possible importance of interaction between carbohydrates.

There is a growing awareness that sugars are not only catabolized by the oral flora but may act as substrates for the synthesis of polysaccharides. Gibbons \& Socransky (1962) found that the plaque microflora from subjects with high caries activity produced more intracellular iodophilic polysaccharide than plaque obtained from individuals with low caries activity. They suggest that such polysaccharides can be formed from environmental carbohydrates and utilized as a reserve energy source in the absence of an external supply of substrate.

It has been shown recently (Leach, 1965) that the extracellular carbohydrate accumulating in the dental plaque is not derived from salivary glycoprotein, as hitherto believed, but is in the main composed of dextran and levan, the synthesis of which require the presence of sucrose. Gibbons, Berman, Knoettner \& Kapsimalis (rg66) have shown in gnotobiotic rats that certain strains of streptococci which are cariogenic can synthesize more capsular and extracellular polysaccharide from sucrose than from glucose.

Sucrose may therefore function as a cariogenic agent in two ways, by providing an energy supply for the oral flora and by acting as a substrate for levan synthesis in the dental plaque. The polysaccharide formed could then act as a reserve source of energy when external supplies are not available. It may be that in the presence of other metabolizable substrates the utilization of sucrose is lessened, thereby depressing the amount of glycogen synthesized. If this were true it would go some way to explain why an uncooked starch-sucrose mixture was more cariogenic than equivalent amounts of roll-dried starch and sucrose. The rate of hydrolysis of roll-dried starch by salivary amylase is likely to be higher than that of uncooked starch, thus providing more substrate which could be fermented by the flora of the dental plaque and depressing the use of sucrose.

If this hypothesis is correct, then diets containing glucose and fructose, or mixtures 
of equal quantities of glucose and sucrose, should be less cariogenic in the rat than sucrose alone. This we intend to test.

We wish to thank Tate and Lyle Limited for the icing sugar and Corn Products Limited for the roll-dried maize starch. We also thank Miss B. M. Morrison for her skilled technical assistance. Grateful thanks are expressed to the Medical Research Council for a grant to defray the expenses of this work.

\section{REFERENCES}

Gibbons, R. J., Berman, K. S., Knoettner, P. \& Kapsimalis, B. (1966). Archs oral Biol. II, 549.

Gibbons, R. J. \& Socransky, S. S. (1962). Archs oral Biol. 7, 73.

Grenby, T. H. (1963). Archs oral Biol. 8, 27.

Grenby, T. H. (1966). Br. dent. F. 121, 26.

Green, R. M. \& Hartles, R. L. (1966a). Br. F. Nutr. 20, 317.

Green, R. M. \& Hartles, R. L. (1966b). Archs oral Biol. Ix, 727.

Green, R. M. \& Hartles, R. L. (I966c). Archs oral Biol. II, 9 I3.

Hartles, R. L. \& Lawton, F. E. (1957). Br. F. Nutr. II, I3.

Hartles, R. L. \& Leaver, A. G. (I961). Archs. oral Biol. 5, 38.

König, K. G., Marthaler, T. M. \& Mühlemann, H. R. (1958). Dt. Zahn-Mund-u. Kieferheilk. 29, 99.

Leach, S. A. (1965). Advances in Fluorine Research and Dental Caries 3, 187. London: Pergamon Press.

Molan, P. C. \& Hartles, R. L. (1966). Archs oral Biol. Ir, I I63.

Rozeik, F. (1958). Dt. Zahnärztl. Z. 13, 66.

Schweigert, B. S., Shaw, J. H., Phillips, P. H. \& Elvehjem, C. A. (I945). F. Nutr. 29, 405. 